\begin{tabular}{|c|c|c|c|}
\hline $\begin{array}{l}\text { A Case } \\
\text { Study }\end{array}$ & $\begin{array}{r}\text { ADVANCE RESEARC } \\
\text { Volume } 10 \mid \text { Issue } 2 \mid\end{array}$ & $\begin{array}{l}\text { SOCIAL SCIENCE } \\
\text { ISSN-0976-5611 }\end{array}$ & \\
\hline $0=$ & DOI: 10.15740/HAS/ARJSS/10.2/70-74 & Visit us : www.researchjournal.co.in & \\
\hline
\end{tabular}

\title{
Surrogacy in India: Present perspective and related issues
}

Neha Wasal

Arya College, Ludhiana (Punjab) India

(Email : neha_wasal@yahoo.com)

\begin{tabular}{|c|c|}
\hline \multicolumn{2}{|c|}{ ARTICLE INFO : } \\
\hline Received & 23.09 .2019 \\
\hline Accepted & 27.11 .2019 \\
\hline
\end{tabular}

KEY WORDS :

Surrogacy in India,

Related issues

HOW TO CITE THIS ARTICLE :

Wasal, Neha (2019). Surrogacy in India:

Present perspective and related issues.

Adv. Res. J. Soc. Sci., 10 (2) : 70-74, DOI:

10.15740/HAS/ARJSS/10.2/70-74.

Copyright@2019:HindAgri-Horticultural Society

\begin{abstract}
The surrogacy (Regulation) Bill, 2019 was introduced by the Minister of Health and Family Welfare, Dr. Harsh Vardhan in Lok Sabha on July 15, 2019. The Bill defines surrogacy as a practice where a woman gives birth to a child for an intending couple with the intention to hand over the child after the birth to the intending couple. This paper has taken many issues related to surrogacy. This paper is based on secondary data and deep review of literature. There are issues like psychological and economic conditions of surrogate mothers which are never taken into consideration. There are few psychological issues which are related with surrogacy and surrogates. These issues are emotional attachment of surrogate mother with child, feeling of dissatisfaction, feeling of conflict, depression when surrendering the child, grief and even refusal to release the child, child's psychology gets affected. It was found from the study that the most common emotion or emotional problem which surrogates have faced during and before surrogacy was feeling of fear and there has always been a feeling of sadness among surrogates. On the other hand, very few surrogates feel trusty feeling for the commissioned parents.There are some legal issues which are related with the surrogate mothers and their rights. There is a lack of awareness about the contact of surrogacy, which is done between surrogates and commissioned parents. Then another legal issue related to surrogacy is the citizenship given to the child.
\end{abstract}

